\title{
TUNNELLING THE PENINSULA OF TROLLS: A CASE STUDY OF ROAD INFRASTRUCTURE IMPROVEMENT AND DEMOGRAPHIC DYNAMICS IN NORTHERN ICELAND
}

Thoroddur Bjarnason ${ }^{1}$

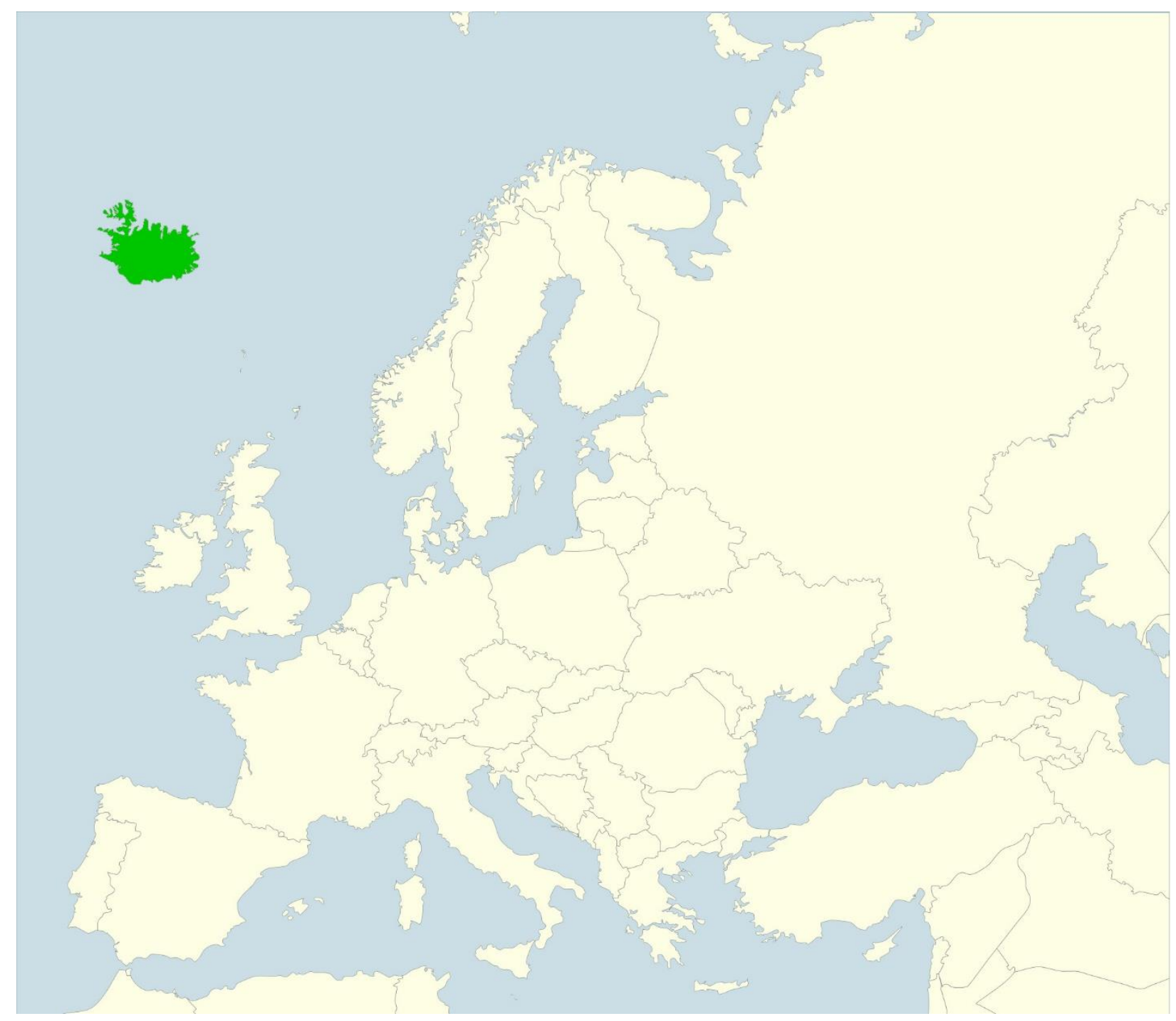

${ }^{1}$ Prof. Thoroddur Bjarnason, Faculty of Social Sciences, University of Akureyri, Iceland, e-mail: thorodd@unak.is, ORCID: 0000-0002-1400-231X 
Abstract: Geographical isolation is closely associated with rural population decline and policies for regional and rural development frequently emphasize better transportation infrastructure improvements. Although poor access to jobs and services may lead to negative rates of net migration and skewed age and gender distribution in rural and remote areas, research on the association of road infrastructure improvement with rural demographic dynamics remains sparse. The current study adds to the understanding of these issues by examining the effects of a large-scale road tunnel project in Northern Iceland. The results suggest that improved road infrastructure coincides with a break in long-term population decline through parity in net migration and positive changes in the composition of the population of sparsely populated areas.

Key words: Tunnels - demography - coastal communities - Iceland

Yfirlit: Landfræðileg einangrun er nátengd fólksfækkunar í dreifðum byggðum og við stefnumörkun í byggðamálum er oft lögð áhersla á samgöngubætur. Pótt takmarkað aðgengi að störfum og pjónustu geti leitt til neikvæðs flutningsjöfnuðar og skekktrar aldurs- og kynjadreifingar í strjálbýli hafa fáar rannsóknir verið gerðar á áhrifum samgöngubóta á lýðfræði dreifðra byggða. Pessi rannsókn eykur skilning á pessu efni með pví að taka stórframkvæmdir í gangnagerð á Norðurlandi til nánari athugunar. Niðurstöðurnar benda til pess að samgöngubætur tengist stöðvun langvarandi fólksfækkunar með pví að stuðla að flutningsjöfnuði og jákvæðum breytingum á samsetningu mannfjöldans í dreifðum byggðum.

Lykilorð: Jarðgöng, Lýðfræði, Sjávarbyggðir, Ísland

\section{Highlights:}

- Rural development policies often emphasize road infrastructure improvements

- The effects on rural populations have rarely been studied

- A set of two tunnel connected previously isolated towns in Northern Iceland

- Infrastructure improvements were associated with positive population development, net migration and age distribution

\section{Introduction}

Geographical isolation generally coincides with rural population decline. Many sparsely populated areas in the vicinity of major cities thus frequently enjoy population growth while their more remote counterparts tend to decline and lose younger people in particular (Grimsrud, 2010; Johnson \& Lichter, 2019; Salvia et al., 2020). The lack of access to higher education, well-paid and prestigious jobs, public services, retail, entertainment and a rich social life are thus among the major predictors of future migration expectations among rural youth, in particular among young women (Bjarnason \& Thorlindsson, 2006; Corbett, 2013; Rauhut and Littke, 2016; Skrbis et al., 2014; Thissen et al., 2010). The out-migration of younger people may subsequently lead to a vicious circle of economic decline and loss of services (Elshof et al., 2014; Thiede at al., 2017; Vias, 2006) and a demographic drag of low fertility and high mortality that leads to further population decline in the future (Johnson et al., 2015; Martínez-Filgueira, 2017).

Policies for regional and rural development frequently emphasize better transportation infrastructures to counteract economic stagnation and population decline (Bisaschi et al., 2021; Dubois \& Roto, 2012; OECD, 2006, 2019). While many such infrastructure projects primarily expand the reach of cities into rural hinterlands, other projects incidentally or by design improve transportation within and between sparsely populated regions. Prior research has emphasized the effects of infrastructure improvements on patterns of commuting from rural areas to cities (e.g. 
Lavesson, 2017; Partridge et al., 2010; Tveter, 2018), but a few studies have also mapped lateral work travel between rural areas (Bjarnason, 2014; Lian \& Rønnevik, 2010; Tveter et al., 2017). In some cases, better road infrastructure leads to increased commuting and/or population growth in sparsely populated areas, but in other cases, no such effects are observed (Levkovich et al., 2019; Lian \& Rønnevik, 2010; Tveter et al., 2017).

In this context, it is important to note that rural population change involves complex dynamics of migration patterns and natural population change (Johnson et al., 2015; Martínez-Filgueira, 2017). The predictors of in-migration may differ from the predictors of out-migration and the magnitude of both births and deaths can be attributed to either individual-level fertility and life expectancy or compositional effects of the relative number of younger and older people in the area.

The current study adds to the understanding of the role of transport infrastructure improvements in population dynamics by examining a large-scale road tunnel project in Northern Iceland. In the following sections, prior research on the effects of transport infrastructure on population change will be reviewed and the specific objectives of the case study will be described in more detail. Changes in local traffic are then outlined, followed by a detailed examination of changes in population, migration rates, and age and gender distribution in the first decade after the opening of the tunnels. The paper concludes by discussing the findings in the broader context of transport infrastructure improvements in sparsely populated areas.

\section{Literature review}

Towards the end of the $19^{\text {th }}$ century, Ebenezer Howard (1898) famously advocated garden cities connected to major cities by direct railroad links as a policy to combine the advantages of urban and rural living. This vision of combining urban and rural amenities by rail was however eclipsed by the diffuse suburbanization of 20th century. Across different continents, the mass production of automobiles and the development of national highway systems led to the decline of central cities and the growth of vast suburban residential zones (Levkovich et al., 2019; Baum-Snow, 2007; Baum-Snow et al., 2017; Garcia-López et al., 2015; Kopecky \& Suen, 2010).

Massive infrastructure projects involving e.g. tunnels, bridges and high-speed trains have further expanded the reach of major cities, contributing to regional convergence in GDP (Fageda \& Olivieri, 2019), narrowing the urban-rural income gap (Huang et al., 2020) and increasing longdistance commuting (Garmendia et al., 2011). As an example, about 18,000 commuters traversed the Øresund bridge between Copenhagen and the Swedish region of Skån each day (Knudsen \& Rich, 2013). These cross-border commuters were roughly equally divided between Swedes taking advantage of new work opportunities in Copenhagen and Danes taking advantage of lower housing prices in Skån while continuing to work in Copenhagen.

On a smaller scale, fixed links with small island communities have frequently been found to be associated with increased day tourism, second-home ownership and commuting to the mainland (Baldacchino, 2007). Indeed, replacing ferry services with bridges seems to have been associated with population growth on islands in the global North ranging from Canada (Guay, 2007) to France (Barthon, 2007), Ireland (Royle, 2007) and Sweden (Källgård, 2007). Such positive effects of fixed island links may however be dependent on various local factors, such as the island and mainland population size, distance to the next larger urban center and various other economic and social considerations (Lian \& Rønnevik, 2010; Tveter et al., 2017).

In many countries, investments in transport infrastructure have become an important part of rural and regional policy to enhance equity and efficiency, create larger rural markets for jobs, goods and services and stimulate regional growth (Bisaschi et al., 2021; Dubois \& Roto, 2012; Moss et al., 2004; OECD, 2019; Partridge et al., 2010; Sandow, 2008; Thorsen, 1998; Tveter et al., 2017). From a metrocentric perspective, the geographical expansion of urban hinterlands is the main advantage of expanding transportation systems into sparsely populated rural areas. In particular, such expansions provide rural residents with easy access to urban jobs and city dwellers with opportunities to move their homes to more rural settings. There is indeed formidable evidence of the positive effects of better access to urban job markets on rural population retention and growth 
in various Western countries (e.g. Chi, 2012; lacono \& Levinson, 2016; Lavesson, 2017; Levkovich et al., 2019; Moss et al., 2004; Partridge et al., 2010; Sandow, 2008).

Improvements of rural transportation infrastructures not only provide better connections between sparsely populated areas and major cities, but may also change the relations between rural towns, villages and farming communities (Bjarnason, 2014). Poor access to jobs and services is frequently cited as a major reason for population decline and skewed age and gender distributions in rural and remote areas (e.g. Bjarnason \& Thorlindsson, 2006; Corbett, 2013; Rauhut \& Littke, 2016; Skrbis et al., 2014; Thissen et al., 2010).

Better and shorter roads may expand the geographical scope of job opportunities in traditional rural extraction industries such as farming, fishing, logging or mining, public services such as education or health, and various small businesses and entrepreneurial enterprises that provide jobs, for example, electricians, plumbers and carpenters as well as IT-specialists, therapists and tour guides. Beyond employment opportunities, improved road infrastructure in sparsely populated areas may also enhance access to e.g. entertainment and cultural events, sports clubs for children, cheaper and more diverse retail and a wide range of other public and private services. Such improvements of quality of life increase the likelihood of local residents staying in rural communities as well as the attractiveness of the area for potential in-migrants.

In the Norwegian context, Lian and Rønnevik (2010) and Tveter et al. (2017) each assess the effects of several large-scale road infrastructure project on population change. Their findings illustrate the importance of distinguishing between projects that bring sparsely populated areas within commuting distance of regional centers, provide connections between equally large towns, or connect rural areas with one another.

Projects that expanded the reach of Stavanger urban area (pop. 237 thousand) by replacing ferries with a 26 minutes' drive led to substantial increases in commuting and population growth in two islands with 3 thousand inhabitants each. Tveter et al. (2017) conclude that in these cases, population growth could to a considerable extent be attributed to urban people taking advantage of lower island housing prices and commuting back to the mainland.

In other cases, local amenities appeared to be a more important factor. Projects that in 1989 and 1993 brought islands with 3 thousand and 7 thousand inhabitants within 20-30 minutes driving distance of Fredrikstad (pop. 82 thousand) and Bergen (pop. 284 thousand) did not result in an increase in work travel but the rural populations nevertheless grew substantially (Tveter et al., 2017). People relocating to these areas thus seem to have been drawn by the combination of local amenities and easy access to the cities.

The Norwegian road infrastructure projects that enabled long-distance commuting to cities yielded mixed results. Establishing a fixed road link instead of a ferry in 2008 brought two islands with population of 5 thousand and 7 thousand within 70-90minute driving distance from Ålesund (pop. 66 thousand), resulting in population growth on the islands (Tveter et al., 2017). In contrast, the 2001 Triangle connection brought three islands, with populations of 3-15 thousand each, within 60-75 minutes from Haugesund (pop. 37 thousand). This project did result in substantial increases in commuting but there is no evidence of increased population growth (Tveter et al., 2017). There were however shifts in population between the island communities and an increase in second homes owned by people living about 2.5 hours away in the larger cities of Bergen and Stavenger (Lian \& Rønnevik, 2010).

For the purposes of the current study, the Norwegian road infrastructure projects that linked small towns and sparsely populated areas to one another are particularly relevant. Tveter et al. (2017) report substantial population growth in two of the three cases where fixed links established in 1990-2000 brought islands with populations of 3-4 thousand within 70-80minute driving distance from mainland towns with populations of 5-8 thousand. Lian and Rønnevik (2010) however did not find evidence of increased population growth as a result of a 1995 tunnel that reduced traveling time between two towns of 9 thousand and 13 thousand inhabitants to less than an hour, but reported growth in the more rural region between the two towns. In 1999, a set of three tunnels and four bridges in Northern Norway reduced travel time between an island with about 3 thousand inhabitants and the equally rural mainland area from 45 minutes by ferry to about 20 minutes by 
car but did not seem to have an effect on either commuting patterns or the long-term population decline (Lian \& Rønnevik, 2010).

\section{Objectives of the current study}

The research reviewed above strongly suggests that expanding the reach of cities into sparsely populated areas generally results in rural population growth. Infrastructure improvements that enable long commutes to regional centers or link two or more smaller communities sometimes but not always result in increased work travel and population growth.

The current study examines the association of a large-scale road tunnel project with population dynamics in two coastal communities in Northern Iceland. First, the long-term population development in the area is considered in the context of population change in other coastal communities. Second, levels of in-migration and out-migration in the affected communities are examined, as well as changes in net migration compared to other coastal communities. Finally, changes in the age and gender distribution of the local population are evaluated with an emphasis on the absolute number of women of childbearing age and younger children in the communities, compared to other coastal communities.

\section{Settings}

Iceland is characterized by a monocentric concentration of two-thirds of the national population of 364 thousand in the Reykjavík capital area and an additional 15\% in the exurban region within one-hour commuting from the city center (Statistics Iceland, 2020a). The other settlements around the $5,000 \mathrm{~km}$ coastline include about seventy urban towns and villages and about three thousand family farms mostly based on sheep and cattle husbandry. The population density of 3.5 inhabitants per $\mathrm{km}^{2}$ makes Iceland by far the most sparsely populated country in Europe (Eurostat, 2020). This figure is however somewhat misleading as the populated areas are mostly limited to coastal areas and the highlands covering most of the island are uninhabitable. Most of the population lives within 200 meters above sea level at an overall density of about 14.7 inhabitants pr. $\mathrm{km}^{2}$, but the density of the lowland population outside the Reykjavík capital area is about 5.4 inhabitants per $\mathrm{km}^{2}$.

For a millennium after the Norse settlement of the island in the $9^{\text {th }}$ century, Iceland was a sustenance farming society with a very rudimentary transportation system. Most domestic travel was by foot, horse or occasionally coastal boats, without any transportation system of roads, rivers or canals. Foreign merchants operated trading posts around the island but there were no year-round urban settlements until the village of Reykjavík was established in 1751. Road construction started in Iceland in the 19th century, but the national road system did not reach all settlements until shortly after WWII. The backbone of the national road system is the two-lane ring road opened in 1974 and completely paved with asphalt by 2019. The ring road threads the main towns around the coast with many smaller settlements and farming communities connected to the ring road by narrower, frequently gravel roads.

Regional development strategies in Iceland have emphasized road infrastructure improvements (Bjarnason, 2014; Parliament of Iceland, 2018). This includes smaller projects such as paving roads with asphalt, broadening older roads and replacing single-lane bridges over creeks and rivers with dual-lane bridges, as well as more expensive projects of bridges across fjords and road tunnels through mountains. Out of the twelve road tunnels in Iceland ranging from $0.8 \mathrm{~km}$ to $9.1 \mathrm{~km}$, one is on the ring road in the vicinity of the Reykjavík capital area, six are in the Westfjords or the Eastfjords and five tunnels are in the mountainous northern area shown in Figure 1.

The northern regional center of Akureyri is by far the largest urban concentration beyond the southwest with about 20,000 inhabitants in 2020, providing a wide range of administrative, economic, social and cultural functions for Northern and Eastern Iceland. Akureyri is for instance the home to the regional hospital, a small university, an airport servicing domestic flights and international charter flights, a harbor servicing container ships, large trawlers and cruise ships, an outpost from the national broadcasting corporation, a local TV station and regional newspaper, 
a professional theatre and symphony orchestra, two movie theatres and about 40 restaurants, cafés and pubs, a mid-sized mall and a fledgling underground market for illicit drugs.

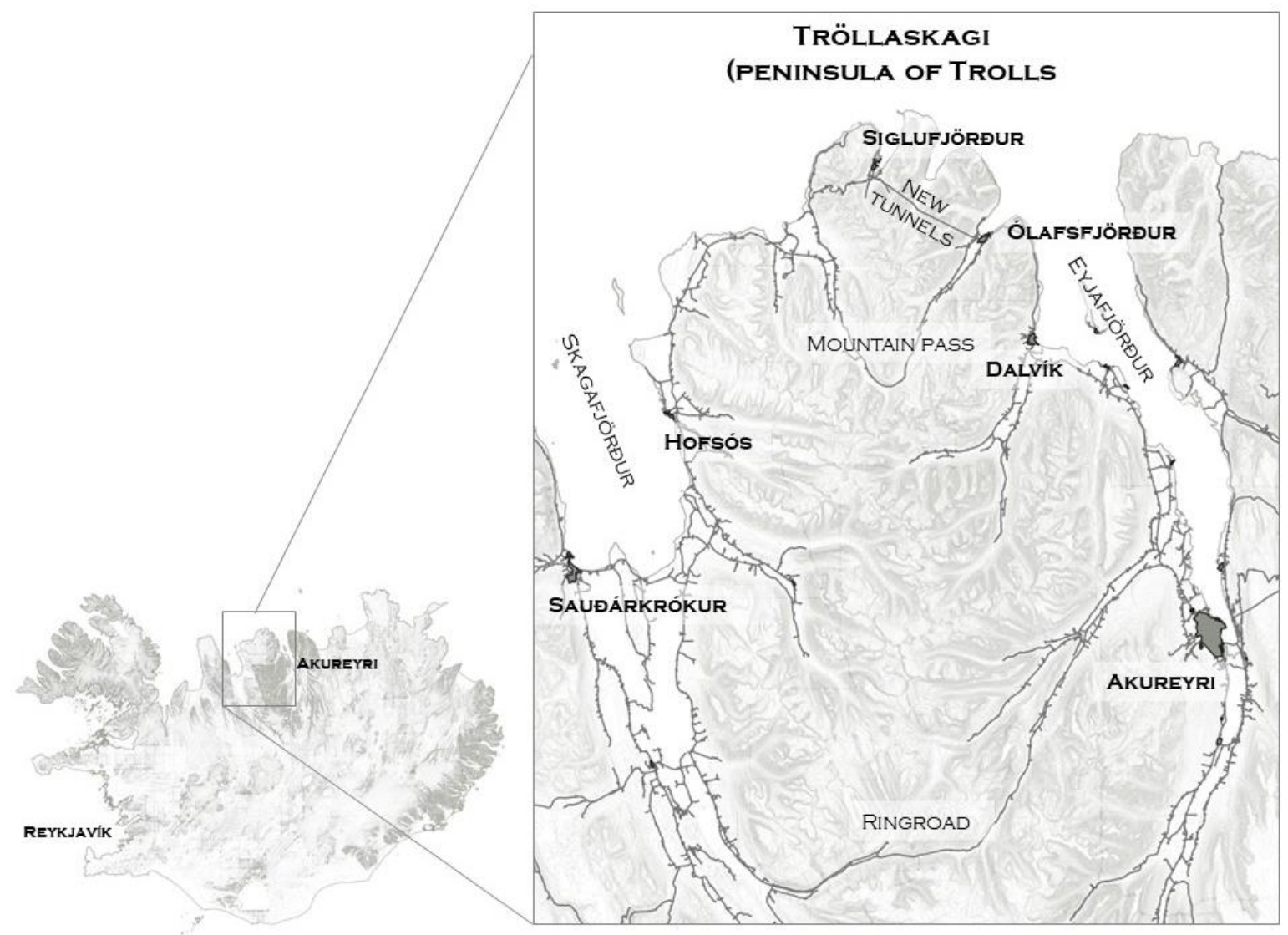

Fig 1. Urban settlements and roads in the study area.

In the Tröllaskagi (Peninsula of Trolls) mountain range north of Akureyri, the two towns of Siglufjörður and Ólafsfjörður were historically quite isolated. They first came into road connection with the outside world in the mid-1940s, albeit via mountain passes that were closed much of the winter and connected both towns towards the Northwest region. Getting to the regional center of Akureyri in the Northeast region, thus involved a several hour journey over a mountain pass to the west side of the mountain range, threading a narrow road to the bottom of the fjord and then again east over a second mountain pass to Akureyri.

In the mid-1960, a perilous cliff road was built on the east side of the peninsula, connecting the town of Ólafsfjörður directly to Akureyri and other communities in the Northeast region. Around the same time, a new single-lane tunnel connected the town of Siglufjörður more firmly to the Northwest region.

In 2000, the government authorized the construction of the Héðinsfjörður tunnels, a set of two road tunnels connecting the two towns via the abandoned fjord between them, and the two towns merged into the joint municipality of Fjallabyggd in 2006. The main objectives were to (1) connect the two towns, (2) bring Siglufjörður closer to the regional center of Akureyri and the Northeast region, (3) open a second year-round route between the Northeast and the Northwest regions, and (4) create new opportunities in tourism by creating a circle around the Tröllaskagi peninsula (Bjarnason, 2015). In the process, the tunnels were expected to reverse decades of population decline by creating more diverse opportunities for employment, services and leisure activities in the two towns.

When the tunnels opened in 2010 , the two towns became close neighbors $17 \mathrm{~km}$ apart instead of the earlier distance of $62 \mathrm{~km}$ in summer and $233 \mathrm{~km}$ in winter. The tunnels enabled the merger of the two towns into the joint municipality of Fjallabyggð, accompanied by considerable municipal and governmental reorganization of education, health and safety. In many cases, the slightly 
larger Siglufjörður gained more than Ólafsfjörður from the merger, leading to some resentment among the residents of the latter town.

It is important to note that the tunnels changed the social geography of two towns in different ways. Apart from the new neighbor to the west, Ólafsfjörður (pop. 800) remained in the same position with $17 \mathrm{~km}$ to the next similar town of Dalvík (pop. 1,400) and $61 \mathrm{~km}$ from the regional center of Akureyri. In contrast, Siglufjörður (pop. 1,200) effectively moved from the Northwest region to the Northeast region. Before the tunnels, the closest neighbor of Siglufjörður to the west were the village of Hofsós (pop. 180) at a distance of $60 \mathrm{~km}$ and the town of Sauðárkrókur (pop. 2,640) at a distance of $96 \mathrm{~km}$. In addition to Ólafsfjörður, the tunnels also gained Siglufjörður the new neighbor of Dalvík $34 \mathrm{~km}$ away and the distance to the regional center of Akureyri diminished from $123 \mathrm{~km}$ in summer and $192 \mathrm{~km}$ in winter before the tunnels to $77 \mathrm{~km}$ all year round after the tunnels.

It should be noted that while the more sparsely populated areas of Iceland incurred considerable population losses in the last decades of the $20^{\text {th }}$ century, rural net migration rates improved considerably in the first decades of the $21^{\text {st }}$ century (Gardarsdottir et al., 2020). This can be attributed to various factors, in particular the explosive growth of tourism in Iceland from about 460 thousand international tourists in 2010 to 2.3 million in 2018 (Saethorsdottir et al., 2020). While the bulk of international tourists stay within a short tour-bus distance of Reykjavík, the massive increase in the flow of tourists on the ring road around the island has benefited coastal villages and farming communities in all regions of the country.

The opening of the Héðinsfjörður tunnels in 2010 coincided with the international tourism explosion and enabled considerable private investment in tourism infrastructure in Siglufjörður in particular. In addition, the tunnels strengthened the market for second homes and made it easier for owners to spend more time in their second homes (Huijbens, 2012). The tunnels also strengthened the fishing industry by providing easier transportation of fish and enabled commuting between and beyond the two towns (Bjarnason 2014). While the new $77 \mathrm{~km}$ route from Siglufjörður to the regional center of Akureyri did not result in increased long-distance commuting (Bjarnason, 2014), it did enable access to a wide range of services and improved the perceived quality and diversity of health services available to residents (Gustafsdottir et al., 2017).

In an examination of the demography of Ólafsfjörður and Siglufjörður in the decades leading up to the opening of the tunnels, Bjarnason et al. (2010) showed that the two towns experienced substantially more net out-migration and greater population decline than neighboring coastal communities. The age structure of the two towns was more skewed and the population was on average 3-6 years older than in the other coastal communities. In the first decade of the 20th century, the age groups 20-40 declined by more than a third and the number of children under the age declined to half the number ten years previously. Bjarnason et al. (2010) concluded that unless in-migration would substantially change the age and gender composition of the municipality, the population would decline by 39 percent over the next two decades and the average age would increase by ten years.

\section{Data and methods}

Data on traffic flows on all roads to and from the two towns based on permanent traffic counters were obtained from the Icelandic Road Authority (2020). This includes traffic on the Siglufjarðarvegur road (section 76-07), Ólafsfjarðarvegur road (section 82-05), the mountain pass across the Lágheiði mountain pass (section 82-09) and the Héðinsfjörður tunnels (section 76-15). It should be noted that these figures reflect traffic volume but not the number of actual cars or individuals traveling the areas since the same car can pass one or more traffic counter on specific routes and the average number of passengers per car may vary over time.

Data on population development as well as age and gender distribution in the two towns and other coastal communities in the period 1881-2020 were obtained from the Statistics Iceland (2020b, 2020c) databank of urban nuclei. Other coastal communities in Iceland are defined as the 44 towns and villages in Iceland that (1) have a harbor, (2) have fewer than three thousand 
inhabitants and (3) are beyond the approximately $75 \mathrm{~km}$ exurban radius of the capital of Reykjavík.

It is important to note that the objective here is not to isolate an appropriate "control-group" from the universe of Icelandic coastal communities, but to present the concrete example of Fjallabyggð against the backdrop of the development of actual Icelandic coastal communities. Such communities are to a different degree affected by long-term macro changes in e.g. climate, economy, technology and government policy and short-term and idiosyncratic events such as establishment or bankruptcy of companies, arrival, departure or death of entrepreneurs, natural disasters or local environmental change. These effects may differ systematically by structural factors such as community size, location and economic base as well as community-specific sociocultural factors such as social capital or resilience.

Data on in-migration and out-migration obtained from Statistics Iceland (2020d) are only available on the municipal level. It is therefore not possible to present changes in migration patterns in Fjallabyggð in the context of other coastal communities specifically. Instead, these changes are presented against the backdrop of migration patterns in the 24 rural municipalities in Iceland where coastal communities include largest concentrations of municipal residents. While roughly comparable to data on urban nuclei, it should be kept in mind that these data include the migration patterns of both residents of the coastal communities and residents of the farming communities within each municipality.

\section{Results}

The results of this study are presented in four sections. First, all road traffic in the region in the period 2000-2020 is mapped in order to establish changes in traffic patterns associated with the opening of the Héðinsfjörður tunnels in 2010. Second, population trends in the two towns are compared to population trends in other coastal communities to evaluate changes after the opening of the tunnels in the context of wider population trends. Third, municipal-level rates of in-migration, out-migration and net migration are calculated for the period 1991-2009 and net migration rates in Fjallabyggð municipality are compared to net migration rates of other coastal municipalities. Finally, age and gender structure of Fjallabyggð municipality in 2020 is compared with the Fjallabyggð structure in 2010 and with the age and gender structure of other coastal municipalities in 2020.

\section{Traffic flows}

Figure 2 shows regional changes in traffic flows after the opening of the tunnels in 2010. The largest change is the massive increase in traffic between the two towns. In 2009, only 125 cars went over the mountain pass each day on average. In 2011, an average of 548 cars went through the tunnels each day, increasing to 778 each day in 2019. The traffic between the two towns thus increased by a factor of 4.4 in the first full year after the opening of the tunnels, increasing to a factor of 6.2 between 2009 and 2019.

The figure also shows an increase in traffic between the new municipality of Fjallabyggð and the outside world. The combined traffic on the roads towards west and east increased by a factor of 1.4 from 663 per day in 2009 to 968 per day in 2019. The traffic towards the Akureyri regional center increased by a factor of 1.6 from 422 in 2009 to 673 in 2019. The traffic towards the west initially decreased but in the long term increased by a factor of 1.2 from 241 in 2009 to 295 in 2019.

Overall, it can be concluded that the tunnels resulted in a massive increase in traffic between the two towns as well as substantial increase in traffic to and from other places. This includes a wide range of activities; locals and visitors traveling various reasons, including work, education, health services, retail, family visits, sport participation or other leisure activities. In the next section, we will examine the changes in population trends following these fundamental changes in traffic patterns. 


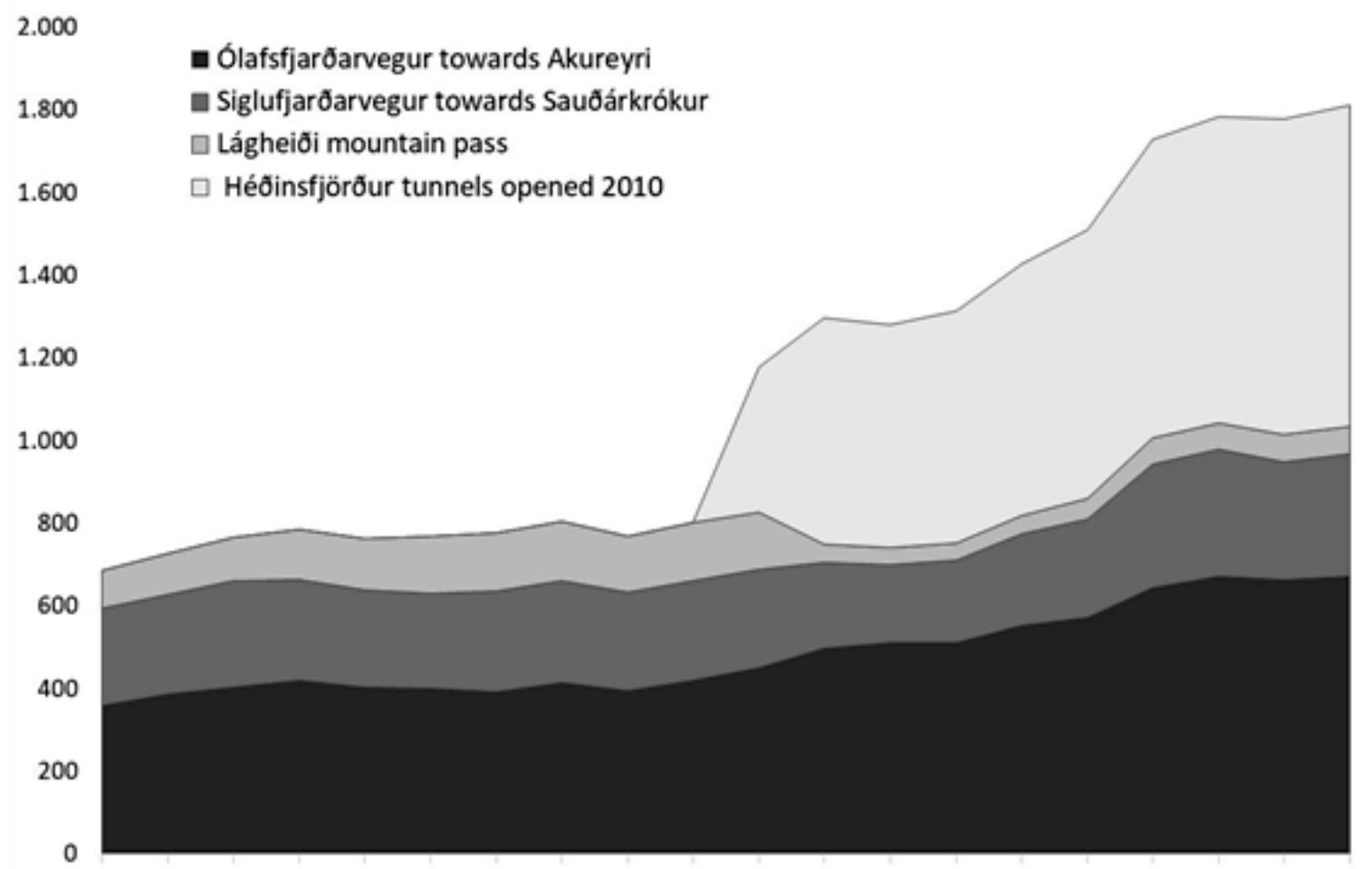

20002001200220032004200520062007200820092010201120122013201420152016201720182019

Fig 2. All main roads to and from Fjallabyggð municipality.

\section{Population development}

Figure 3 shows long-term population development in Siglufjörður and Ólafsfjörður compared to other coastal communities in Iceland over the period 1881-2020. The three lines show the annual population of the two towns and their combined population on the right-hand scale. The stacked area in grey represents the combined population of all other coastal communities in Iceland on the left-hand scale.

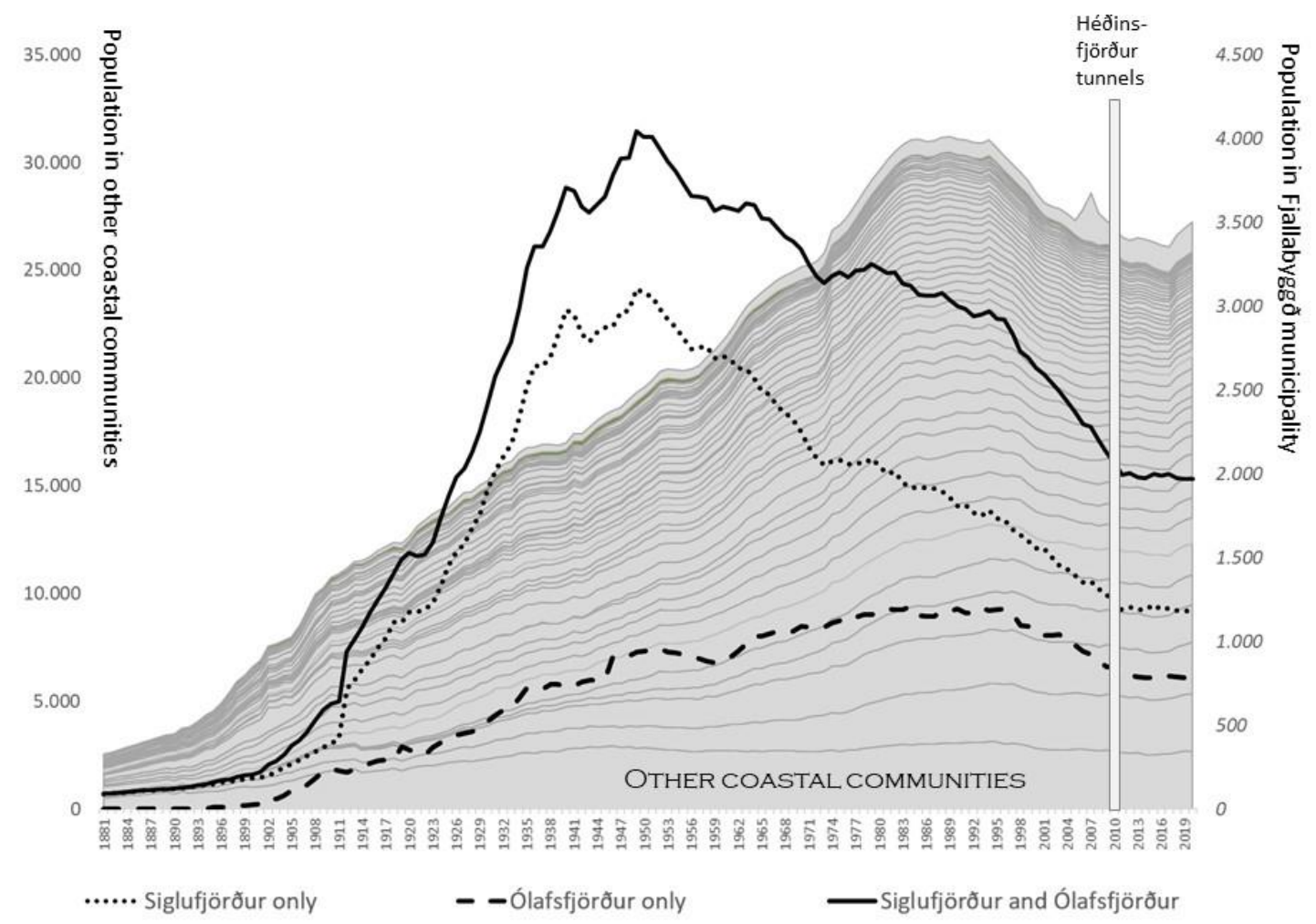

Fig 3. Population development in Fjallabyggð and other coastal communities, 1881-2020. 
Siglufjörður grew quickly around the herring fisheries in the first half of the $20^{\text {th }}$ century and peaked at more than three thousand registered inhabitants after WWII, although the actual number including a large number of transient and seasonal workers was vastly higher (Baldvinsson, 2019). The decline in Siglufjörður population started in the late 1940s as the herring stocks moved further east and eventually collapsed and the population decline continued almost uninterrupted for seventy years. The long-term growth trajectory of Ólafsfjörður in the 20th century was similar to other coastal communities, reaching a peak of 1,300 inhabitants in 1985. As in the other coastal communities, technological and organizational changes in the fisheries led to population decline in Ólafsfjörður in the last decades of the $20^{\text {th }}$ century.

The unbroken line depicting the combined population of these two neighboring towns shows most clearly the abrupt change in population development with the opening of the Héðinsfjörður tunnels in 2010. The combined population of the two towns declined by $-2.5 \%$ annually from 1996 to 2010 , but the net population change remained close to zero $(-0.1 \%)$ in the period $2011-2020$. The opening of the tunnels thus seems to provide to a turning point where population stability was abruptly achieved after decades of population decline.

However, a comparison with the overall population trend in other coastal communities calls for some caution. The turnaround in population trends after the opening of the tunnels coincided with a more general slowing down and eventual reversal of downward population trends in other coastal communities. Although the broad social, cultural and economic changes that may have contributed to greater demographic stability in rural lceland are beyond the scope of the current study, the tunnels thus seem to have contributed to a convergence with the population trends in the other coastal communities. In other words, before the tunnels, the communities under study were more isolated and declined faster than most other coastal communities, but after the tunnels, they seem to develop in a similar fashion as other coastal communities in Iceland.

\section{Migration rates in Fjallabyggd}

Figure 4 shows in-migration, out-migration and net migration in the combined municipality of Fjallabyggð. In-migration increased slightly from 1991 to 2019 with an increase of about $0.5 \%$ inmigrants per year. This growth is somewhat accelerated after the opening of the Héðinsfjörður tunnels with most years at or above the trend line. At the same time, out-migration decreased at a rate of about $0.3 \%$ out-migrants each year. While the out-migration rate was somewhat higher in the years preceding the opening of the tunnels, the long-term change in the rate of out-migration is less clear. As a result of these two trends, net migration has improved at a rate of about $0.8 \%$ migrants each year and is now very close to parity. 


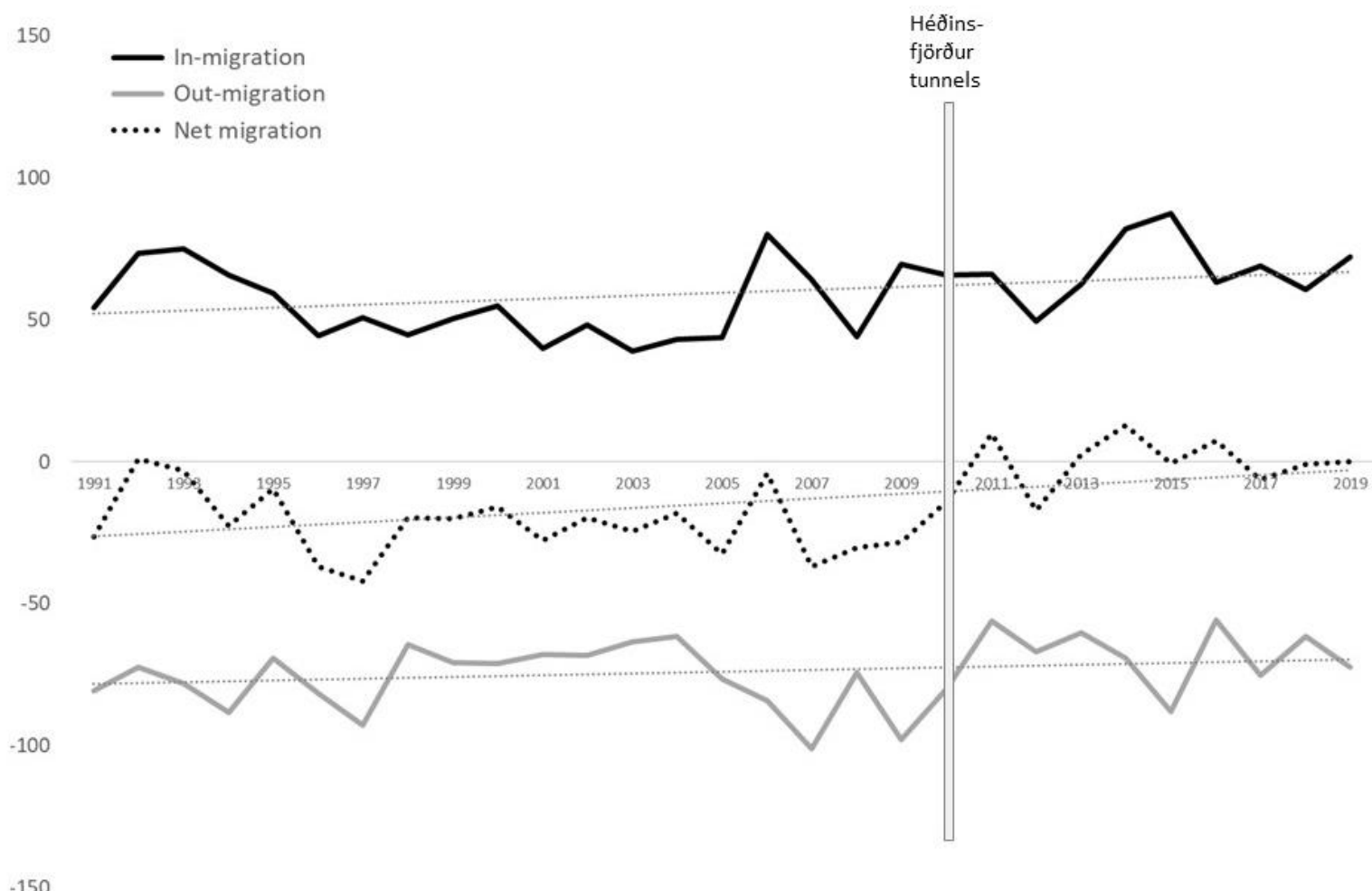

$-150$

Fig 4. In-migration, out-migration and net migration [\%]] in Fjallabyggð municipality, 1991-2019.

Again, the changes in migration patterns in Fjallabyggð after the opening of the Héðinsfjörður tunnels must be evaluated in the context of the turnaround in Icelandic coastal communities. Figure 5 shows the trends in the net migration rate in Fjallabyggð municipality in comparison with other coastal municipalities.

In the period 1991-2010, Fjallabyggð lost population to net migration at a rate of $21.6 \%$ each year. This level of population loss was 33\% higher than the average net migration population loss of $16.2 \%$ in other coastal municipalities in the country. In contrast, both the Fjallabyggð and other coastal municipalities in Iceland were close to a zero net migration rate in the period 2011-2019 with a slightly positive net rate of $0.8 \%$ in-migrants in Fjallabyggð and a slightly negative net rate of $0.8 \%$ out-migrants in other coastal municipalities. 


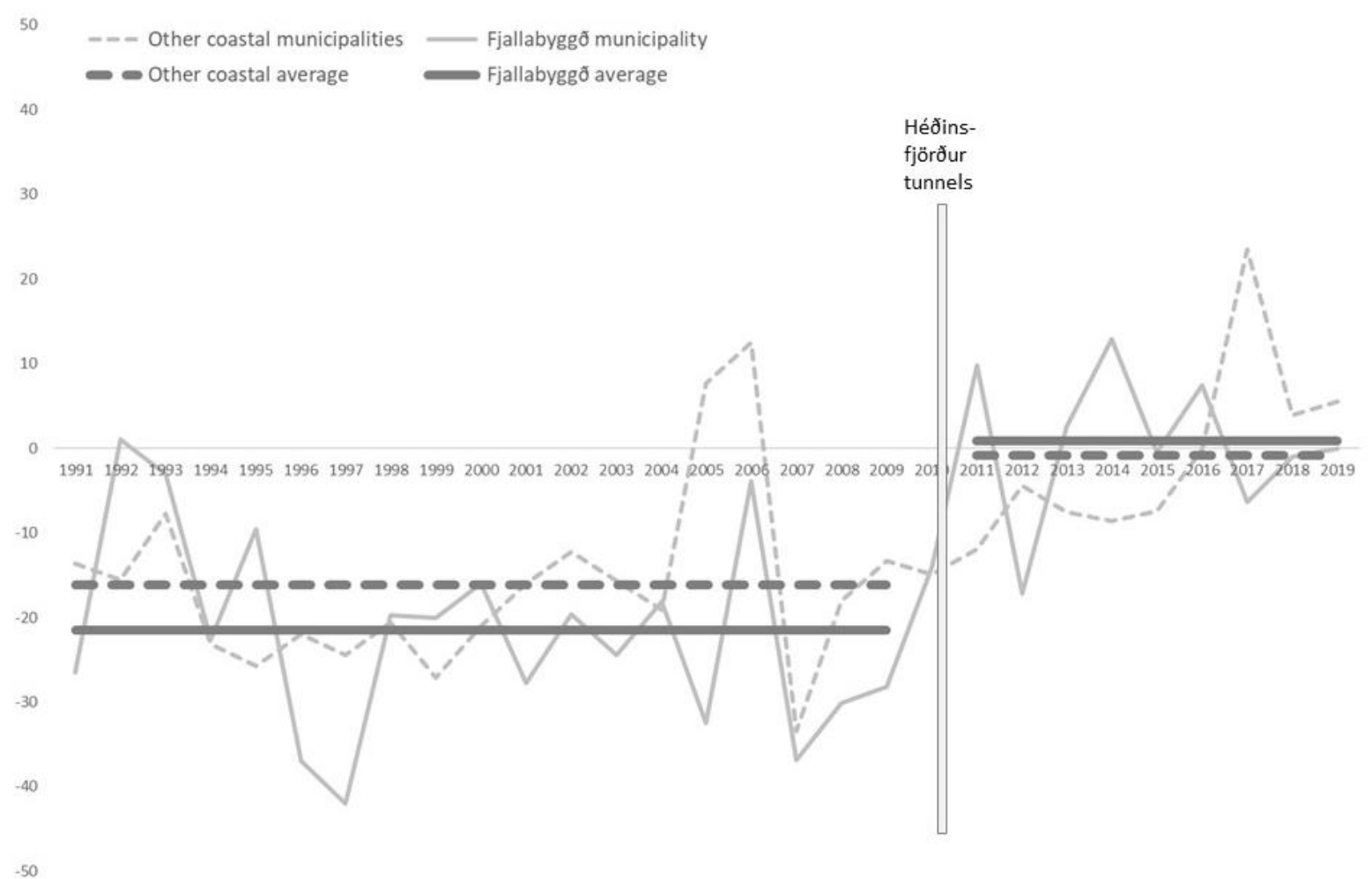

Fig 5. Net migration in Fjallabyggð and other coastal municipalities, 1991-2019.

These results further support the conclusion that the opening of the tunnels brought the municipality of Fjallabyggð from a less favorable demographic trajectory to a trajectory comparable to other coastal municipalities in Iceland.

\section{Age and gender distribution}

Figure 6 shows the population distribution of the two towns by age and gender. The shaded pyramid shows the highly skewed distribution in 2010 when the tunnels opened. For instance, the proportion of 45-54-year-old males and females was almost twice as high as the proportion 25-34-year-old male and female residents. The low number of younger adults was mirrored in the low number of children under the age of ten while the relatively large middle-aged cohorts were mirrored in the larger cohorts of older children and youth.

Ten years later, the large cohorts of people who were 45-54 in 2010 were found in the equally large cohorts who were 54-64 in 2020, suggesting a relatively stable and still healthy albeit aging group. The mortality rate in these cohorts will inevitably increase in the next decades, but the effects of this demographic "time bomb" will depend on the net migration rates of the younger cohorts.

Figure 6 shows encouraging changes in this respect. As could be expected, many from the large cohorts of children and youth aged 10-19 in 2010 have been lost to out-migration ten years later. However, the very small 2010 cohorts of 25-34-year-old people have grown considerably as 3544-year-old ten years later, indicating age-specific in-migration. Furthermore, in 2020, the proportion of 25-34-year-old males and females had become similar to the proportions of their 45-54-year-old counterparts. While the small cohorts of children under the age of ten in 2010 are reflected in small cohorts of children and youth aged 10-19 in 2020, the new cohorts of children under the age of ten are substantially larger. 


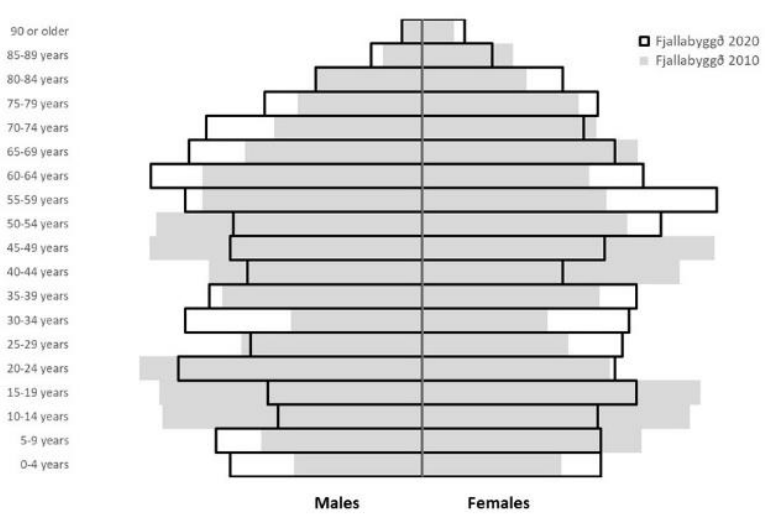

Fig 6. Population distribution in Fjallabyggð municipality in 2020 compared to 2010.

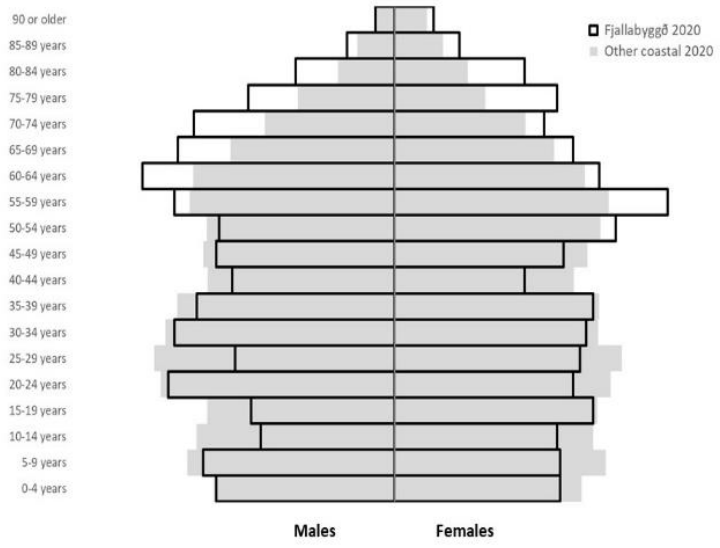

Fig 7. Population distribution in Fjallabyggð compared to other coastal communities in 2020.

Figure 7 compares the age distribution of Fjallabyggð with other Icelandic coastal municipalities in 2020. It shows that despite a considerably less skewed population distribution compared to 2010, Fjallabyggð still has proportionately older residents than other coastal municipalities. In fact, the proportion of residents in all age groups under the age of 55 is lower in Fjallabyggð than the other communities. While the distribution became much less skewed after the tunnel, Fjallabyggð continues to be older than other coastal communities, which in turn are older than the population of Iceland as a whole.

Finally, Figure 8 focuses on the changes in the number of women aged 20-39 and children under the age of ten in Fjallabyggð and other coastal communities in Iceland in the period 2001-2020. In order to facilitate the comparison of the trends, the number in each group is set to 100 in 2001.

For every 100 women 20-39 years old in Fjallabyggð in 2001, there were only 60.0 when the tunnel opened in 2010 but their numbers gradually increased to 76.1 in 2020 . For every 100 women in these age groups in other coastal communities in 2001 there were 83.6 women in 2010 and 89.0 women in 2010. In the first decade of the 21st century, the number of women of childbearing age thus declined much faster in Fjallabyggð than other coastal communities, with a difference in the 10-year decline of 23.6 (83.6-60.0) pr. 100 women. The overall reversal in the next decade was more pronounced in Fjallabyggð than other coastal communities, leading to a 20 -year difference of 12.9 (89.0-76.1) pr. 100 women.

For every 100 children under the age of 10 in Fjallabyggð in 2001, there were only 52.6 when the tunnel opened in 2010 and their relative number further declined to 50.4 in 2012, representing about half the number of children who were in these communities at the turn of the century. Subsequently, however, the number of younger children in Fjallabyggð had increased to 60.1 in 2020. In other coastal communities, the number of children under the age of 10 also declined to 81.9 in 2010 and continued to decline to a low of 76.4 in 2020. The difference in the 10 -year decline was thus 29.3 (52.6-81.9) pr. 100 children by 2010 but had reduced to 16.3 (60.1-76.4) pr. 100 children by 2020 .

In summary, Fjallabyggð shows considerable evidence of a demographic drag as large cohorts of older people and small birth cohorts from before the Héðinsfjörður tunnels continue to move up the population pyramid. In-migration has substantially corrected the earlier skewness of the age and gender distribution, even though the distribution remains more skewed than in other coastal municipalities in Iceland. Once again, the tunnels seem to have contributed to a convergence between the population dynamics in Fjallabyggð and the other coastal communities. 


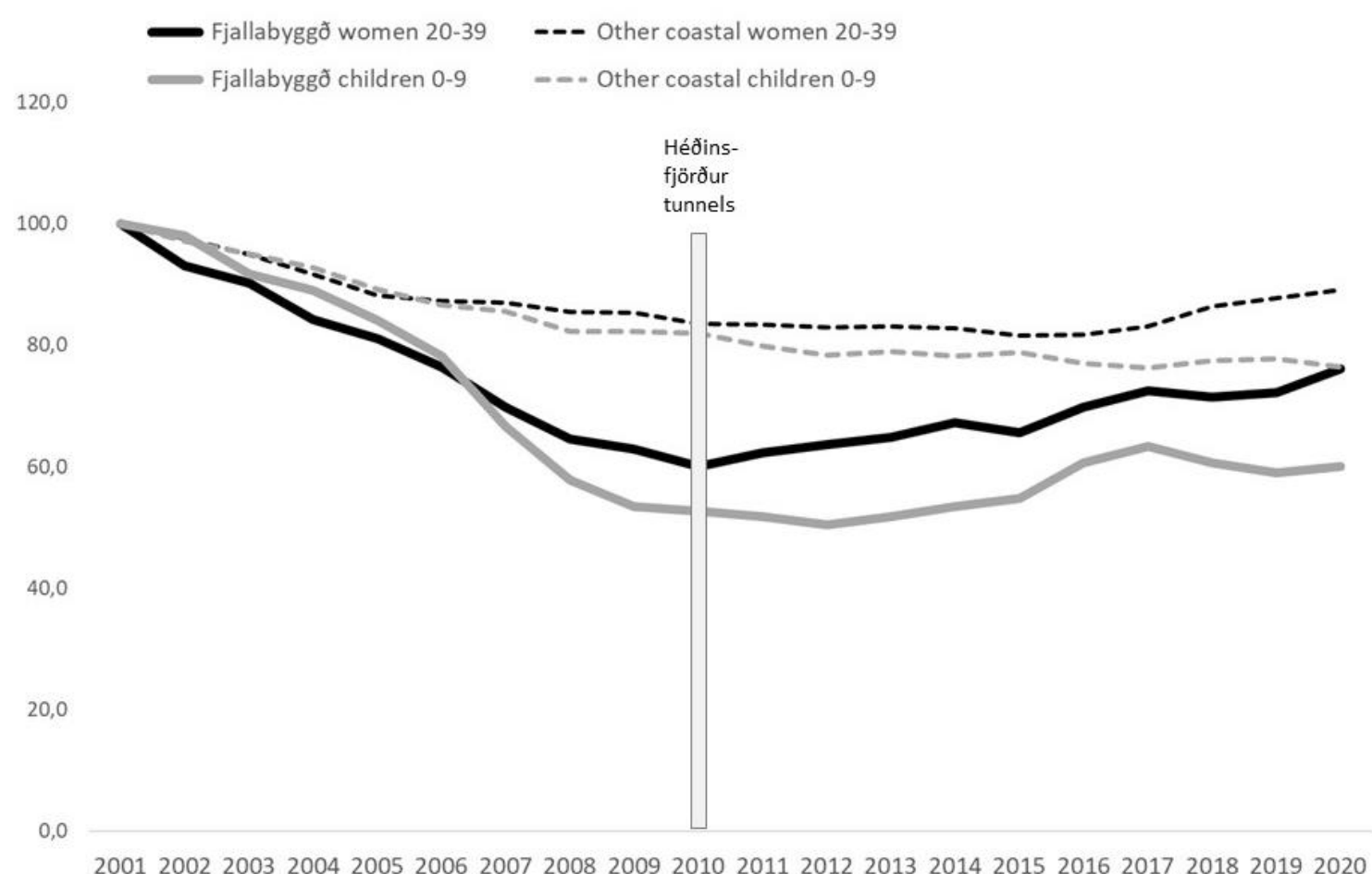

Fig 8. Changes in the relative number of younger women and young children in Fjallabyggð and other coastal communities in Iceland, 2001-2020.

\section{Discussion}

The bulk of research on the effects of road infrastructure improvements in sparsely populated areas has focused on the availability of jobs and commuting patterns of professionals and skilled, semi-skilled and unskilled workers in "thin labor markets" (Manning, 2003; see also e.g. Herslund, 2012; Moss et al., 2004; Sandow \& Westin, 2010; Tonts, 2010). Better and shorter roads may thus expand the geographical scope of job opportunities in traditional rural extraction industries such as farming, fishing, logging or mining, public services such as education or health, and in various small businesses and entrepreneurial enterprises, providing jobs, for e.g. electricians, plumbers and carpenters as well as IT-specialists, therapists and tour guides.

Previous research has demonstrated that while the Héðinsfjörður tunnels transformed the labor market of the towns within $17 \mathrm{~km}$ distance of one another, there was no increase in long-distance $77 \mathrm{~km}$ commuting from Siglufjörður to the regional center of Akureyri (Bjarnason, 2014). Interestingly, however, the tunnels substantially increased the work travel of professionals and skilled workers from Akureyri to Siglufjörður, perhaps reflecting the thin market for specialized knowledge in the regional center. Future studies should further explore the extent to which road infrastructure improvements contribute to the size and cohesion of rural labor markets. Furthermore, in addition to urban workers taking advantage of rural housing markets and increased rural commuting towards urban areas, future studies should explore further the economic and social effects of increased commuting of professionals living in urban centers into rural areas.

It should also be noted that sparsely populated areas can also be considered "thin markets" for several other aspects of everyday life, including e.g., education, health care, shopping, entertainment, dating, religious or political activities, sports participation and other voluntary associations. In addition to infrastructure improvements that expand the reach of cities, better roads can also increase the social density of sparsely populated areas. Transport infrastructure improvements that shorten travel time between cities and sparsely populated areas thus contribute to rural population retention and growth by simultaneously providing rural residents with easy access to city amenities and city workers with opportunities to establish homes in more sparsely populated areas (e.g. Chi, 2012; lacono \& Levinson, 2016; Lavesson, 2017; Levkovich 
et al., 2019; Tveter et al., 2017). While only $8 \%$ of the employed population in Fjallabyggð work in the regional center of Akureyri, more than half had been to an Akureyri discount supermarket in the past 30 days and in the past year, almost half had been to an Akureyri bookstore, about a third had been to a clothing store or to the movies and about a quarter had been to a specialist doctor (Gallup, 2017).

Although rural and regional policies frequently emphasize the importance of investments in transport infrastructure, studies have however shown mixed results of road infrastructure projects linking small towns and sparsely populated areas to one another on population development (Lian \& Rønnevik, 2010; Tveter et al., 2017). In some cases, population growth or decline continued regardless of transportation improvements, while in other cases strong positive effects are observed.

In this context, it is important to note that this study presents actual demographic changes in Fjallabyggð after the tunnels against the backdrop of the overall demography of Icelandic coastal communities that have experienced both common long-term economic, social and cultural changes and a wide range of short-term community-specific events. It does not attempt to provide statistical proof of causality by comparing Fjallabyggð with a control group of otherwise comparable communities that were not affected by infrastructure improvements or other major shocks in the period under study. While the transformation of the Icelandic road system has affected virtually all coastal communities in Iceland, the twelve road tunnels constructed in Iceland between 1948 and 2020 as well as the large number of bridges across fjords and rivers and the gradual asphalt paving of most major roads would provide rich data for future studies employing statistical time-series techniques to estimate structural effects of road infrastructure improvement on demographic development in rural communities.

The results of the current study nevertheless suggest that road infrastructure improvements in rural and remote communities may primarily help overcome geographical disadvantages and lead to a convergence in population development with less remote rural areas. The Héðinsfjörður tunnels signaled the end of rapid, long-term population decline in the Fjallabyggð municipality and brought the population development into step with other, generally less remote Icelandic coastal communities.

Overall, population growth or decline may however mask the effects of road infrastructure improvements on the underlying demographic dynamics. Rural population change is the outcome of in-migration, out-migration, births and deaths, and better roads, can directly and indirectly affect each of the four components. Interestingly, no prior research appears to have examined the association of transportation infrastructure improvement with these different components of rural population dynamics.

Better road infrastructure may make it easier for locals to stay, and it may also increase the inmigration of both return migrants and new residents. Our results suggest that the tunnels may have contributed to both an increase in in-migration and a decrease in out-migration, bringing the net migration in Fjallabyggð close to parity. Prior to the tunnels, Fjallabyggð experienced a much more negative rate of net migration than other coastal communities in Iceland. After the opening of the tunnels, the net migration rate in both Fjallabyggð and other coastal communities was close to parity. These findings suggest that the improved road infrastructure may have extended the positive changes that swept Icelandic coastal communities to Fjallabyggð and thus contributed to a convergence in net migration rates.

While road infrastructure improvements are not likely to have a major effect on individual fertility decisions or individual risk of death, they may nevertheless play an important role in natural population change. The magnitude of both births and deaths can be attributed to either individuallevel fertility and life expectancy or compositional effects of the relative number of younger and older people in the area (Johnson et al., 2015; Martínez-Filgueira, 2017). To the extent that road infrastructure improvements affect the age and gender distribution of the population, they may thus indirectly influence the number of births relative to deaths in sparsely populated areas.

In the year the Héðinsfjörður tunnels opened, Bjarnason (2010) warned that the extremely skewed age and gender distribution of Fjallabyggð would likely lead to continued population decline, even 
if net migration parity would be achieved. The current study shows that the older generation in Fjallabyggð is indeed proportionately larger than in other coastal communities, which in turn are older than the Icelandic population as a whole. The older generation will of course eventually die, and future natural population decrease is still a possible scenario in Fjallabyggð. However, the composition of the population of Fjallabyggd is much more favorable, with more younger women and more young children in the community than a decade earlier. Lack of access to various amenities plays an important role in the outmigration of young women from sparsely populated areas (Bjarnason and Thorlindsson, 2006; Corbett, 2013; Rauhut \& Littke, 2016; Skrbis et al., 2014; Thissen et al., 2010). While there are still proportionately few younger women in Fjallabyggð, their increasing number may perhaps be partially explained by the enlarged and denser rural area and better access to the more diverse regional center of Akureyri.

In summary, the current study highlights the fact that while road infrastructure improvements do not magically eliminate the challenges facing sparsely populated areas, they may positively impact demographic dynamics. The parity in net migration and the positive changes in the composition of the population are thus the underlying causes of the apparent end of long-term population decline in Fjallabyggð.

\section{Acknowledgements}

This work was supported by the Icelandic Road Authorities Research Fund (Rannsóknasjóður Vegagerðarinnar and the Icelandic Regional Development Institute (Byggðastofnun). The paper has benefited considerably from extended discussions with Jón Porvaldur Heiðarsson and other colleagues at the University of Akureyri.

Academic references

[1] Amcoff, J. (2009). Rapid regional enlargement in Sweden: A phenomenon missing an explanation. Geografiska Annaler. Series B, Human Geography, 91(3), 275-287. DOI: 10.1111/j.1468-0467.2009.00320.x.

[2] Baldacchino, G., ed. (2007). Bridging Islands: The Impact of "Fixed Links". Charlottetown: Acorn Press.

[3] Baldvinsson, P. B. (2019). Síldarárin 1867-1969. Reykjavík: JPV.

[4] Barthon, C. (2007). Bridge impacts on islands off the west coast of France. In Baldacchino, G., ed., Bridging Islands: The Impact of "Fixed Links" (pp. 219-235). Charlottetown: Acorn Press.

[5] Baum-Snow, N. (2007). Did highways cause suburbanization? The Quarterly Journal of Economics, 122(2), 775-805. DOI: 10.1162/qjec.122.2.775.

[6] Baum-Snow, N., Brandt, L., Henderson, J. V., Turner, M. A. \& Zhang, Q. (2017). Roads, railroads, and decentralization of Chinese cities. The Review of Economics and Statistics, 99(3), 435-448. DOI: 10.1162/rest_a_00660.

[7] Bisaschi, L., Romano, F., Carlsberg, M., Carneiro, J., Ceccanti, D., Calofir, L. \& Skinner, I. (2021). Transport Infrastructure in Low-Density and Depopulating Areas. Brussels: European Parliament, Policy Department for Structural and Cohesion Policies.

[8] Bjarnason, T. (2014). The effects of road infrastructure improvement on work travel in northern Iceland. Journal of Transport Geography, 41, 229-238. DOI: 10.1016/j.jtrangeo.2014.09.009.

[9] Bjarnason, T. (2015). Samgöngur og byggðapróun: Samfélagsleg áhrif Héðinsfjarðarganga. íslenska pjóđfélagiđ, 6(1), 5-36. 
[10] Bjarnason, T. \& Thorlindsson, T. (2006). Should I stay or should I go? migration expectations among youth in Icelandic fishing and farming communities. Journal of Rural Studies, 22(3), 290-300. DOI: 10.1016/j.jrurstud.2005.09.004.

[11] Bjarnason, T., Olafsson, K. \& Stefansson, K. (2010). Búsetupróun í Fjallabyggð. In Bjarnason, T. \& Stefansson, K., eds., Fjallabyggð fyrir Héðinsfjarðargöng: Samgöngur, Samfélag og Byggđapróun (pp. 50-57). Akureyri: University of Akureyri.

[12] Chi, G. (2012). The impacts of transport accessibility on population change across rural, suburban and urban areas. Urban Studies, 49(12), 2711-2731. DOI: $10.1177 / 0042098011431284$.

[13] Corbett, M. (2013). I'm going to make sure I'm ready before I leave: The complexity of educational and mobility decision-making in a Canadian coastal community. Journal of Rural Studies, 32, 275-282. DOI: 10.1016/j.jrurstud.2013.07.006.

[14] Dubois, A. \& Roto, J. (2012). Making the best of Europe's Sparsely Populated Areas: On making Geographic Specificity a Driver for Territorial Development in Europe [working paper] Stockholm: NORDREGIO.

[15] Elshof, H., Wissen, L. \& Mulder, C. H. (2014). The self-reinforcing effects of population decline: An analysis of differences in moving behaviour between rural neighbourhoods with declining and stable populations. Journal of Rural Studies, 36, 285-299. DOI: 10.1016/j.jrurstud.2014.09.006.

[16] Fageda, X. \& Olivieri, C. (2019). Transport infrastructure and regional convergence: A spatial panel data approach. Papers in Regional Science, 98(4), 1609-1631. DOI: $10.1111 /$ pirs.12433.

[17] Garcia-López, M., Holl, A. \& Viladecans-Marsal, E. (2015). Suburbanization and highways in Spain when the romans and the bourbons still shape its cities. Journal of Urban Economics, 85, 52-67. DOI: 10.1016/j.jue.2014.11.002.

[18] Gardarsdottir, Ó, Bjarnason, T., Jónsson, S. H. \& Shuttleworth, I. (2020). Is internal migration declining in Iceland? intensities, geographical patterns and population composition 19862017. Population Space and Place. DOI: 10.1002/psp.2339.

[19] Garmendia, M., Ureña, J. M. \& Coronado, J. M. (2011). Long-distance trips in a sparsely populated region: The impact of high-speed infrastructures. Journal of Transport Geography, 19(4), 537-551. DOI:10.1016/j.jtrangeo.2010.06.002.

[20] Grimsrud, G. M. (2011). How well does the 'counter-urbanisation story' travel to other countries? the case of Norway. Population Space and Place, 17(5), 642-655. DOI: $10.1002 / p s p .655$.

[21] Guay, L. (2007). Two Islands in the Saint Lawrence River: One Bridged; One Unbridged. In Baldacchino, G., ed., Bridging Islands: The Impact of "Fixed Links" (pp. 105-122). Charlottetown: Acorn Press.

[22] Gustafsdottir, S. S., Fenger, K., Halldorsdottir, S. \& Bjarnason, T. (2017). Social justice, access and quality of healthcare in an age of austerity: Users' perspective from rural Iceland. International Journal of Circumpolar Health, 76(1), Art. 1347476. DOI: 10.1080/22423982.2017.1347476.

[23] Herslund, L. (2012). The rural creative class: Counterurbanisation and entrepreneurship in the Danish countryside. Sociologia Ruralis, 52(2), 235-255. DOI: 10.1111/j.14679523.2011.00560.x.

[24] Howard, E. (1898). Garden Cities of To-Morrow. London: Swan Sonnenschein \& Co.

[25] Huang, Z., Xu, H., Li, J. \& Luo, N. (2020). Has highway construction narrowed the urbanrural income gap? Evidence from Chinese cities. Papers in Regional Science, 99(3), 705723. DOI: $10.1111 /$ pirs.12504. 
[26] Huijbens, E. H. (2012). Sustaining a village's social fabric? Sociologia Ruralis, 52(3), 332352. DOI: 10.1111/j.1467-9523.2012.00565.x.

[27] lacono, M. \& Levinson, D. (2016). Mutual causality in road network growth and economic development. Transport Policy, 45, 209-217. DOI: 10.1016/j.tranpol.2015.06.005.

[28] Johnson, K. M. \& Lichter, D. T. (2019). Rural depopulation: Growth and decline processes over the past century. Rural Sociology, 84(1), 3-27. DOI: 10.1111/ruso.12266.

[29] Johnson, K. M., Field, L. M. \& Poston, D. L. (2015). More deaths than births. Population and Development Review, 41(4), 651-680. DOI: 10.1111/j.1728-4457.2015.00089.x.

[30] Källgård, A. (2007). Sweden, islands and bridges. In Baldacchino, G., ed., Bridging Islands: The Impact of "Fixed Links" (pp. 251-260). Charlottetown: Acorn Press.

[31] Knudsen, M. A. \& Rich, J. (2013). Ex post socio-economic assessment of the Öresund bridge. Transport Policy, 27, 53-65. DOI: 10.1016/j.tranpol.2012.12.002.

[32] Kopecky, K. A. \& Suen, R. M. H. (2010). A quantitative analysis of suburbanization and the diffusion of the automobile. International Economic Review, 51(4), 1003-1037. DOI: 10.1111/j.1468-2354.2010.00609.x.

[33] Lavesson, N. (2017). When and how does commuting to cities influence rural employment growth? Journal of Regional Science, 57(4), 631-654. DOI: 10.1111/jors.12324.

[34] Levkovich, O., Rouwendal, J. \& van Ommeren, J. (2019). The impact of highways on population redistribution: The role of land development restrictions. Journal of Economic Geography, 20(3), 783-808. DOI: 10.1093/jeg/lbz003.

[35] Lian, J. I. \& Rønnevik, J. (2010). Ringvirkninger av store vegprosjekter i norge. Oslo: Transportøkonomisk Institutt.

[36] Manning, A. (2003). The real thin theory: Monopsony in modern labour markets. Labour Economics, 10(2), 105-131. DOI: 10.1016/s0927-5371(03)00018-6.

[37] Martínez-Filgueira, X., Peón, D. \& López-Iglesias, E. (2017). Intra-rural divides and regional planning: An analysis of a traditional emigration region (Galicia, Spain). European Planning Studies, 25(7), 1237-1255. DOI: 10.1080/09654313.2017.1319465.

[38] Mohíno, I., Solís, E. \& Urena, J. M. (2016). Changing commuting patterns in rural metroadjacent regions: The case of Castilla-la Mancha in the context of Madrid, Spain. Regional Studies, 51(7), 1115-1130. DOI: 10.1080/00343404.2016.1156238.

[39] Moss, J. E., Jack, C. G. \& Wallace, M. T. (2004). Employment location and associated commuting patterns for individuals in disadvantaged rural areas in Northern Ireland. Regional Studies, 38(2), 121-136. DOI: 10.1080/0034340042000190118.

[40] Partridge, J. \& Nolan, J. (2009). Commuting on the Canadian prairies and the urban/rural divide. Canadian Journal of Administrative Sciences, 22(1), 58-72. DOI: 10.1111/j.19364490.2005.tb00361.x.

[41] Partridge, M. D., Ali, K. \& Olfert, M. R. (2010). Rural-to-urban commuting: Three degrees of integration. Growth and Change, 41(2), 303-335. DOI: 10.1111/j.1468-2257.2010.00528.x.

[42] Rauhut, D. \& Littke, H. (2016). 'A one way ticket to the city, please!' on young women leaving the Swedish peripheral region Västernorrland. Journal of Rural Studies, 43, 301-310. DOI: 10.1016/j.jrurstud.2015.05.003.

[43] Royle, S. A. (2007). Islands off the Irish Coast and the 'Bridging Effect'. In Baldacchino, G., ed., Bridging Islands: The Impact of "Fixed Links" (pp. 203-218). Charlottetown: Acorn Press.

[44] Saethorsdottir, A. D., Hall, C. M. \& Wendt, M. (2020). Overtourism in Iceland: Fantasy or reality? Sustainability, 12(18), Art. 7375. DOI: 10.3390/su12187375. 
[45] Salvia, R., Egidi, G., Salvati, L., Rodrigo-Comino, J. \& Quaranta, G. (2020). In-between 'Smart' urban growth and 'Sluggish' rural development? reframing population dynamics in Greece, 1940-2019. Sustainability, 12(15), Art. 6165. DOI: 10.3390/su12156165.

[46] Sandow, E. \& Westin, K. (2010). The persevering commuter: Duration of long-distance commuting. Transportation Research Part A, 44, 433-445. DOI: 10.1016/j.tra.2010.03.017.

[47] Sandow, E. (2008). Commuting behaviour in sparsely populated areas: Evidence from northern Sweden. Journal of Transport Geography, 16(1), 14-27. DOI: 10.1016/j.jtrangeo.2007.04.004.

[48] Skrbis, Z., Woodward, I. \& Bean, C. (2013). Seeds of cosmopolitan future? Young people and their aspirations for future mobility. Journal of Youth Studies, 17(5), 614-625. DOI: 10.1080/13676261.2013.834314.

[49] Thiede, B. C., Brown, D. L., Sanders, S. R., Glasgow, N. \& Kulcsar, L. J. (2017). A demographic deficit? local population aging and access to services in rural america, 19902010. Rural Sociology, 82(1), 44-74. DOI: 10.1111/ruso.12117.

[50] Thissen, F., Fortuijn, J. D., Strijker, D. \& Haartsen, T. (2010). Migration intentions of rural youth in the Westhoek, Flanders, Belgium and the Veenkoloniën, the Netherlands. Journal of Rural Studies, 26(4), 428-436. DOI: 10.1016/j.jrurstud.2010.05.001.

[51] Thorsen, I. (1998). Spatial consequences of changes in the transportation network: Theoretical analysis and numerical experiments within a multizonal three sector model. Papers in Regional Science, 77(4), 375-406. DOI: 10.1111/j.14355597.1998.tb00723.x.

[52] Tonts, M. (2010). Labour market dynamics in resource dependent regions: An examination of the western australian goldfields. Geographical Research, 48(2), 148-165. DOI: 10.1111/j.1745-5871.2009.00624.x.

[53] Tveter, E. (2018). Using impacts on commuting as an initial test of wider economic benefits of transport improvements: Evidence from the Eiksund connection. Case Studies on Transport Policy, 6(4), 803-814. DOI: 10.1016/j.cstp.2018.10.002.

[54] Tveter, E., Welde, M. \& Odeck, J. (2017). Do fixed links affect settlement patterns: A synthetic control approach. Research in Transportation Economics, 63, 59-72. DOI: 10.1016/j.retrec.2017.07.002.

[55] Vias, A. C. (2006). Population change, economic restructuring, and the evolving landscape of retail activities in the rural Great Plains. Journal of Rural Social Sciences, 21(2), 1-22.

\section{Other sources}

[56] Eurostat (2020). Population density. Accessed at https://ec.europa.eu/eurostat/databrowser/view/tps00003/default/table?lang=en.

[57] Gallup (2017). Pjónustusókn á Norðurlandi Eystra [Service]. Sauðárkrókur: Icelandic Regional Development Institute. Accessed at https://www.byggdastofnun.is/static/files/Skyrslur/thjonustukonnun2018/6-nordurlandeystra-loka.pdf.

[58] Icelandic Road Authority (2020). Umferđá Pjóđvegum [Traffic on National Roads]. Accessed at http://www.vegagerdin.is/upplysingar-og-utgafa/umferdin/umfthjodvegum/.

[59] OECD (2006). The New Rural Paradigm: Policies and Governance. Paris: Organisation for Economic Co-operation and Development. Retrieved from https://www.oecdilibrary.org/governance/the-new-rural-paradigm_9789264023918-en.

[60] OECD (2019). OECD Regional Outlook 2019: Leveraging Megatrends for Cities and Rural Areas. Paris: Organisation for Economic Co-operation and Development. Retrieved from https://www.oecd.org/regional/oecd-regional-outlook-2019-9789264312838-en.htm. 
[61] Parliament of Iceland 2018. Stefnumótandi byggðaáætlun. [Strategic regional plan for Iceland]. Accessed at https://www.althingi.is/altext/148/s/1242.html.

[62] Statistics Iceland. 2020a. Population by municipality, age and sex 1998-2020. Accessed at https://px.hagstofa.is/pxen/pxweb/en/lbuar/lbuar_mannfjoldi_2_byggdir_sveitarfelog/M AN02005.px.

[63] Statistics Iceland. 2020b. Mannfjöldi í einstökum byggđakjörnum og strjálbýli 1880-2018. Accessed at http://px.hagstofa.is/pxis/pxweb/is/Sogulegar/Sogulegar_sogul_mannfjoldi/SOG01010.px.

[64] Statistics Iceland. 2020c. Population by urban nuclei, sex and age 2001-2020. Accessed at https://px.hagstofa.is/pxen/pxweb/en/lbuar/lbuar_mannfjoldi_2_byggdir_Byggdakjarnar/ MAN030101.px.

[65] Statistics Iceland. 2020d. Migration by municipality and sex 1986-2019. Accessed at https://px.hagstofa.is/pxen/pxweb/en/lbuar/lbuar_buferlaflutningar_buferlaflinnanlands buferlaflinnanlands/MAN01201.px. 